Bayero Journal of Pure and Applied Sciences, 5(2): 89 - 92

Received: September 2012

Accepted: December 2012

ISSN $2006-6996$

\title{
STUDY ON PHYSICOCHEMICAL AND HEAVY METALS (Pb, Fe, Mn) CONCENTRATIONS OF TAP WATER IN DUTSE, JIGAWA STATE, NIGERIA
}

\author{
${ }^{1}$ Abdullahi, U.A., and ${ }^{2}$ Indabawa I.I, \\ ${ }^{1}$ Department of Applied Biology and ${ }^{2}$ Department of Plant Science, Bayero University, Kano, P,M.B 3011, Kano \\ Nigeria. \\ ${ }^{1}$ Correspondence author: abdullahidoski@yahoo.com
}

\begin{abstract}
A study on the physicochemical and heavy metals concentration of drinking water in Dutse Jigawa State was conducted between May, 2010 and February 2011. The parameters analyzed were the colour, odour, taste, temperature, turbidity, conductivity, pH, alkalinity, total hardness, dissolved oxygen and some heavy metals (lead, iron and manganese). The water was found to be colourless, odourless, tasteless and free from all suspended particles visible to the nicked eye. The mean temperature, turbidity and conductivity of the water ranged from $26-27^{\circ} \mathrm{C}, 0.006-0.559 \mathrm{NTU}$ and $234-504.8 \mu \mathrm{S} / \mathrm{cm}$ respectively. The $\mathrm{pH}$, alkalinity and total hardness have mean value range of $6.5-7.0,22.5-129 \mathrm{mg} / \mathrm{L}$ and $7.75-16.22 \mathrm{mg} / \mathrm{L}$ respectively. The highest mean value for dissolved oxygen observed was $4.33 \mathrm{mg} / \mathrm{L}$. The results of physicochemical study upon comparison with WHO and NIS standards of drinking water show that, the values were all within permissible limits. The concentration of lead, iron and manganese ranged between $0.09-0.27 \mathrm{mg} / \mathrm{L}, 0.25-$ $0.32 \mathrm{mg} / \mathrm{L}$ and $0.25-0.32 \mathrm{mg} / \mathrm{L}$ respectively. All the values except that of iron exceeded the permissible limits of drinking water recommended by WHO and NIS.

Keywords: Dutse, Drinking water Standard, Heavy metals, Permissible limit, physicochemical, potable water.
\end{abstract}

\section{INTRODUCTION}

Water is a vital resource that covers about $97 \%$ of the earth surface. It is the second most abundant and important resources after air and the essential raw material for human life. Water is a health indicator of any society, community or nation at large (Indabawa, 2002). The presence of reliable source of drinking water is a vital factor in the establishment of community (Yusuf, 2005). However, as well as its life given properties, water also has enormous potentials for spreading ill health and even death if its quality is not properly assessed and state of use been assured (Brown, 1991). It is estimated worldwide that "each year 10 million people die because of drinking contaminated water or water of less quality (WHO, 2004). These among others are the reasons why water quality studies have been receiving attention at several points in time by different researchers.

Drinking or potable water is a water of sufficient high quality that can be consumed or used without fear of immediate or long term harm to the user. Over a large part of the world human have inadequate access to potable drinking water and hence use sources contaminated with unacceptable level of dissolved chemicals and suspended solids as an alternative. Such water is not potable and cannot be used for drinking; using such water leads to widespread of illness and a major cause of death in many countries especially developing ones (Herschy, 1999). To maintain good health, water should be of good quality, meeting the recommended national and international standard of taste, colour, odour and level of chemicals (WHO, 1997). According to WHO (1996), the physical parameters that are likely to give rise to complaints from consumers include colour, taste, odour and turbidity, while low pH causes corrosion of pipe line and high $\mathrm{pH}$ result in a taste complaint.

Heavy metals such as $\mathrm{Pb}, \mathrm{Fe}$, and $\mathrm{Mn}$ tend to be most dangerous because they directly or indirectly enter into food chain and become an increasing health threat (Ademoroti, 1996). The most notable features of metal toxicity is the early effect on behavior and intelligence. Before appearance of any physical signs of disability or diseased condition, area of the brain is damage, out of which arise many neurological and behavioral abnormalities (Yakasai and Atiku, 2010). Levels of heavy metals in water system are one of such water quality that is of great concern and necessary to evaluate. The research was thus aimed at the study of physicochemical properties (colour, taste, odour, temperature, turbidity, electrical conductivity, $\mathrm{pH}$, alkalinity, total hardness and dissolved oxygen), and heavy metals (lead $\mathrm{Pb}$; iron $\mathrm{Fe}$, and manganese $\mathrm{Mn}$ ) concentrations in the sample water with view of comparing the results with WHO 2004 and NIS 2007 standards of drinking water.

\section{MATERIALS AND METHODS \\ Study Area}

The study site (Dutse) is located in the North central part of Nigeria, and is the capital city of Jigawa State. It lies within the geographical coordinate of $11^{0} 45^{\prime} 39^{\prime \prime}$ $\mathrm{N}$ and $9^{\circ} 20^{\prime} 3^{\prime \prime} \mathrm{E}$, and has an estimated population of 17,697 (NPC, 2007), which is the fourth largest town in terms of population behind Hadejia $(111,000)$, Gumel $(43,000)$ and Birnin kudu $(27,000)$. It covers an area of $23,154 \mathrm{~km}^{2}$ (Wikipedia 2009). 
The climate in the area is cyclical (dry and wet seasons) with dry season relatively longer than the wet season and with highest rainfall in July and August.

\section{Sample Collection}

The study was conducted between the period of May, 2010 and February, 2011. Samples were collected on monthly basis from five (5) points across the city for the period of Ten (10) month, depending on the available pump houses that supply water to the city. These points are Shuwarin water works, (the major pump house in the study area), Danmasara pump house, Takur pump house, Garu old city pump house and Dutse model pump house. The samples collected from these points were labeled T1 - T7 and OT. T1 and T2 were samples collected from Shuwarin water works, T3 and T4 from Danmasara pump house, while T5 is a representative of Takur pump house, T6 and T7 were collected from Garu old city water works, lastly OT is the sample collected from Dutse model pump house, which supply water to 1000 housing estate. This was labeled OT because the water pumped here is first stored in overhead tank before supply to the pipe network. Sampling protocols described by American Public Health Association (APHA, 1992) were strictly adhered to during sample collection.

\section{Physicochemical Properties}

Colour, taste and odour were determined through sensory evaluation (that is through seeing, tasting, and smelling the sample) right from the site and directly from the source. Temperature was determined using thermometer (APHA, 1992), pH using dip-in mobile battery operated $\mathrm{pH}$ meter (Ademoroti, 1996), conductivity using EC/TDS meter (Ademoroti, 1996), in which the meter was calibrated and the cell cap was rinsed and filled with the sample, the EC mode button was pressed and the values appear in $\mu S / \mathrm{cm}$. Turbidity was determined using HANNA LP 2000 model turbidity meter (Kolawale, 2007), this was done after the meter was calibrated with $\mathrm{HI}$ 93703-0 and HI 93703-10 NTU standards. Alkalinity and total hardness were determined titrimetrically using $\mathrm{H}_{2} \mathrm{SO}_{4}$ and phenolphthalein/methyl orange indicator and $0.01 \mathrm{M}$ EDTA solution with Eriochrome black $T$ indicator respectively (Indabawa, 2002). Dissolved oxygen was determined using 200 model DO meter (Ademoroti, 1996), while the heavy metals ( $\mathrm{Pb}, \mathrm{Fe}$ and $\mathrm{Mn}$ ) were analyzed using Atomic Absorption Spectrophotometry (AAS) Alpha 4 Chem tech Analytical model, after the samples were digested using single acid digestion method (APHA, 1992).

\section{Statistical Analysis}

Mean and standard deviation (S.D) were computed using Statistical Package for Social Sciences (SPSS, version 15.0 for windows 2003). The mean values obtained were compared with WHO and NIS standards of drinking water.

\section{RESULTS AND DISCUSSION}

The results of physicochemical parameters analyzed showed in Table 1 , reveal that, the mean temperature of all the samples ranges between $26-27.5^{\circ} \mathrm{C}$, with the highest mean temperature of $27.5^{\circ} \mathrm{C}$ observed among overhead tank samples. Turbidity measurement in drinking water is a key test of water quality as high turbidity in water may indicate ineffectiveness in filtration. The mean turbidity of all the samples analyzed fall within the acceptable level of 0-5 (NTU) as recommended by both NIS and WHO standards, in fact the water is believed to be very clear as none of the samples has a mean turbidity value up to 1 NTU. The electrical conductivity of the water samples have the value range of $254-504 \mu \mathrm{S} / \mathrm{cm}$, which falls within $150-1000 \mu \mathrm{S} / \mathrm{cm}$ recommended values by NIS and WHO standards. However, the high mean value of $504.8 \mu \mathrm{S} / \mathrm{cm}$ was observed in over head tank (OT) samples; the overhead tank is metallic and it has been in use for quite long time. This indicates that, the prestorage of the water before distribution affect the electrical conductivity of the water supplied to 1000 housing eatate. $\mathrm{pH}$ is among the most important parameters in operational water quality study and is the measurement of acid-base equilibrium in water. The $\mathrm{pH}$ of good drinking water according to NIS (2007) and WHO (2004) standards for drinking water should be within the range of $6.5-8.5$. The mean values of all the samples analyzed comply with these standards, and they are of course within the neutrality confinement. On the basis of $\mathrm{pH}$ values therefore, the water can be regarded as suitable for drinking. Alkalinity is another important parameter in water quality study; it is the acid neutralizing capacity of water and a function of all titratable bases present in water (Yakasai and Atiku, 2010). High mean alkalinity value was observed in OT sample which was 129 $\mathrm{mg} / \mathrm{L}$ while the lowest mean values were observed among Garu old city (T6 and T7) samples, having 27.9 and $22.5 \mathrm{mg} / \mathrm{L}$ respectively. These mean values fall within $30-500 \mathrm{mg} / \mathrm{L}$ recommended by WHO, and hence, the alkalinity of the water show that all the samples are of good quality. Hard water is water with high mineral content mostly of calcium and magnesium ions. The total hardness of the water analyzed have mean values range of $(7.75-16.22$ $\mathrm{mg} / \mathrm{L})$. And these were found to be below $30-200$ $\mathrm{mg} / \mathrm{L}$ permissible limit recommended by WHO standard. In this respect, the water samples are regarded as soft and fit for use.

The level of heavy metals in water system is one of the qualities that become necessary to evaluate, as their presence at high concentration in water may lead to a significant kind of health risk, especially in long term exposure (Kawo, 2009). The concentration of lead (Pb), (Table 2) in all the samples analyzed was found to be slightly above $0.01 \mathrm{mg} / \mathrm{L}$ recommended by both WHO and NIS standards. This slightly higher concentration may be due to the geographical nature of the sampling site which looks rocky and hilly. Lead $(\mathrm{Pb})$ is a potential contaminant and hence potentially toxic to human life (Yakasai and Atiku, 2010), thus, any increase in concentration above the permissible limit need a serious attention as that may lead to various effect that can only show after prolong period of exposure to that small concentration. 
The Iron (Fe) concentration in all the samples however, shows that the mean values were within the permissible limit of $0.3 \mathrm{mg} / \mathrm{L}$ (NIS, 2007) and 1.0 $\mathrm{mg} / \mathrm{L}(\mathrm{WHO}, 2004)$, and hence, there is no health risk expected with regard to the concentration of iron (Fe). But the concentration of manganese $(\mathrm{Mn})$ in all the samples are above $0.02 \mathrm{mg} / \mathrm{L}$ and $0.05 \mathrm{mg} / \mathrm{L}$ specified by NIS and WHO standards. Thus, prolong exposure may cause chronic effect. The known health impact to a long term exposure to manganese according to NIS (2007) is nuerological disorder.

Table 1: Physicochemical Quality of Tap Water Samples from Various Sources in Dutse

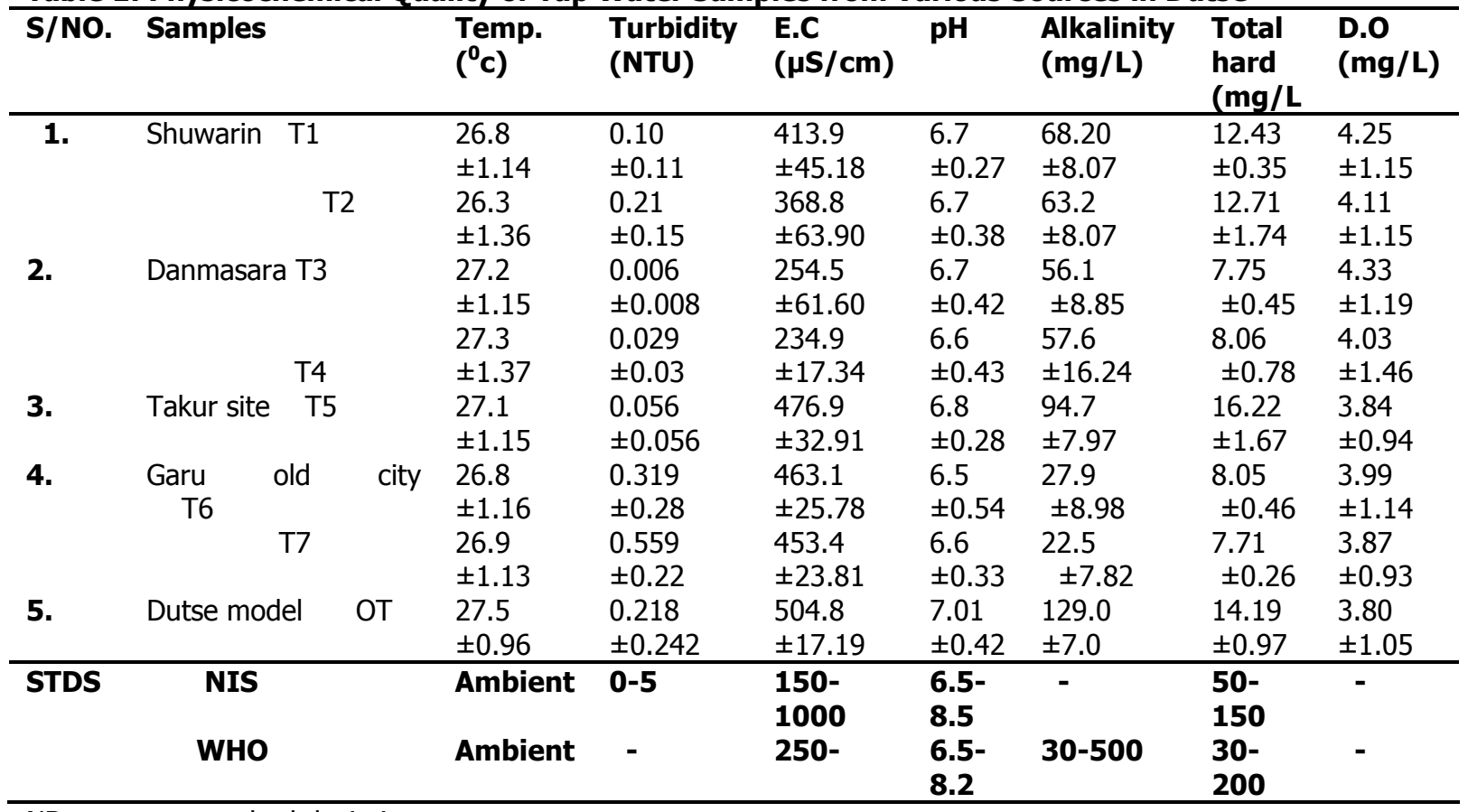

NB: mean \pm standard deviation

Data are mean value of ten replicates

STDS $=$ Standards, NIS $=$ Nigerian Industrial Standard, WHO $=$ World Health Organization

Table: 2 Heavy Metal Contents of Tap Water Samples from Various Sources in Dutse

\begin{tabular}{ccclc}
\hline S/No & Samples & $\mathbf{F e}(\mathbf{m g} / \mathbf{L})$ & $\mathbf{P b}(\mathbf{m g} / \mathbf{L})$ & $\mathbf{M n}(\mathbf{m g} / \mathbf{L})$ \\
\hline $\mathbf{1 .}$ & T1 & $0.29 \pm 0.16$ & $0.09 \pm 0.04$ & $0.29 \pm 0.08$ \\
& T2 & $0.32 \pm 0.20$ & $0.18 \pm 0.18$ & $0.29 \pm 0.12$ \\
2. & T3 & $0.29 \pm 0.15$ & $0.27 \pm 0.26$ & $0.32 \pm 0.21$ \\
& T4 & $0.25 \pm 0.16$ & $0.16 \pm 0.09$ & $0.32 \pm 0.23$ \\
3. & T5 & $0.32 \pm 0.17$ & $0.18 \pm 0.15$ & $0.31 \pm 0.12$ \\
4. & T6 & $0.28 \pm 0.14$ & $0.10 \pm 0.03$ & $0.30 \pm 0.12$ \\
& T7 & $0.30 \pm 0.16$ & $0.15 \pm 0.14$ & $0.24 \pm 0.12$ \\
5. & OT & $0.31 \pm 0.18$ & $0.13 \pm 0.11$ & $0.32 \pm 0.13$ \\
STD & NIS & $\mathbf{0 . 3}$ & $\mathbf{0 . 0 1}$ & $\mathbf{0 . 0 2}$ \\
& WHO & $\mathbf{1 . 0}$ & $\mathbf{0 . 0 1}$ & $\mathbf{0 . 0 5}$ \\
\hline
\end{tabular}

NB: mean \pm standard deviation

Data are mean value of ten replicates

STDS $=$ Standards, NIS $=$ Nigerian Industrial Standard, WHO $=$ World Health Organization

\section{CONCLUSION AND RECOMMENDATION}

The results obtained in this study showed that all the physicochemical parameters analyzed complied with the standard level of drinking water recommended by (WHO, 2004) and (NIS, 2007). However, high mean values in alkalinity and electric conductivity $(129 \mathrm{~m} / \mathrm{L}$ and $504.8 \mathrm{~m} / \mathrm{L}$ ) respectively were noticed in overhead tank samples. Although these values are not higher than the permissible limit recommended by the standards, but condition of the overhead tank need proper attention because excess alkalinity results to a distinct flat and unpleasant taste and scale formation (Orewole et al., 2007). On the other hand, the level of heavy metals especially $\mathrm{Pb}$ and $\mathrm{Mn}$ as shown by the result are above the permissible limit. As such it is recommended that measures should be taken especially by the government to review the condition and take the proper action. 


\section{REFERENCES}

Ademoroti, C. M. (1996). Standard Method for Water and Effluent Analyses. $1^{\text {st }}$ edn. Foludex Ibadan, Nigeria

APHA, (1992). Standard Methods for Examination of Water and Wastewater. $16^{\text {th }}$ edition

Brown, M. (1991). A Practical Guide to Environment $2^{\text {nd }}$ edn

Herschy, R.W. (1999). Hydrometric Principles and Practices. $2^{\text {nd }}$ edn. John Willy and Sons, Chichester. p243.

Indabawa, I.I, (2002). Determination of Alkalinity and Calcium ion Concentration in Water. Hydrobiology Practical Manual, Biological Sciences Department. B.U.K.

Kawo, A.H. (2009). Toxicology and Environmental Pollution. M.Sc. Lecture Series. Department of Biological Sciences, BUK.

Kolawale, Y. A. (2007). The Physico-chemical and Bacteriological Examination of Pipe Borne Water at Kakuri, Makera Settlement in Kaduna. Unpublished M.Tech. Chemistry Dissertation FUT Minna.

NPC (2007), National Population Commission, Reviewed Census 2007.

NIS (2007); Nigerian Standard for Drinking Water. Nigerian Industrial Standard. SON Governing
Council, 13/14 Victoria Arobiek Street, Lekka, Lagos,Nigeria.

Orewole M.O, Mkainde O.W, Adekalu K and Shitu K. A (2007). Chemical Examination of Pipe Water Supply Of Ile - Ife in South - west Nigeria. Iran J. Eviron Health Sci.Eng Vol4 No.1 pP5156.

World Health Organization (WHO), (1996): Guidelines for Drinking Water quality $2^{\text {nd }}$ edn. Geneva Switzerland. Vol. 1-3.

World Health Organization (1997). Health and Environment in Sustainable Development. Five Years after the Earth Summit, (WHO) Geneva, Pp19 - 133.

WHO (2004); Physical and Chemical Standard. Standards for Drinking water Quality.

www.http://.en.wikipedia.org/earthwater, Retrieved August 2009.

www.http://.en.wikipedia.org/dutse, Retrieved January 2010.

Yakasai, H.M. and Atiku, M.K. (2010): Study on Physicochemical Characteristics of Industrial Effluents from Bompai industrial areas, Kano Metropolis. BEST Journal 7(3) $81-86$.

Yusuf, N. (2005): Water Quality Analysis of Pipe Borne Water Supply to Kano Metropolis. Unpublished M.Sc. Geography Dissertation. BUK. 